\title{
The Implementation of South Korea's Military Technology Reform in The Perspective of Techno-nationalism
}

Resi Qurrata Aini ${ }^{1}$, Febry Triantama ${ }^{2}$

resi.aini1@gmail.com, febry.triantama408@gmail.com

${ }^{1}$ Departemen Ilmu Hubungan Internasional, Universitas Indonesia

2Program Studi Ilmu Hubungan Internasional, Universitas Paramadina

DOI https://doi.org/10.22219/sospol.v7i1.14581

\begin{abstract}
Revolution in Military Affairs (RMA) requires fundamental reforms on its three main pillars, namely military technology, doctrine, and organizational reform. South Korea is one of the states that has taken steps to initiate the RMA through defense reform policies. South Korea have initiated its own version of RMA by prioritizing the revolution of military technology rather than any other aspects. This article aims to explain why South Korea prioritizes its military modernization through the development of its domestic defense industry. This research applies the concept of military techno-nationalism impulse with a qualitative approach and literature review method to collect data from official documents, websites of the government, journals, and scientific reports. The results of the research indicate that South Korea's choice to prioritize the development of its domestic defense industry is not merely pushed by the urgency to decrease its dependencies toward the United States, but also by the desire to pursue for strategic power to face the North Korean threat as well as other states around the region that full of antagonism atmosphere, to obtain broader economic benefits through the spin-off effect of industrialization, and to gain international prestige as one of the largest arms exporter as well as standing equal with other regional players.
\end{abstract}

\begin{abstract}
Abstrak
Revolution in Military Affairs (RMA) terbentuk atas pembaharuan fundamental pada tiga pilar utama, yakni teknologi militer, doktrin, dan perombakan organisasi. Korea Selatan merupakan salah satu negara yang mengambil langkah inisiasi RMA melalui kebijakan reformasi pertahanan. Negara ini menginisiasi RMA versinya sendiri dengan lebih mengedepankan pada aspek revolusi teknologi militer. Artikel ini menjelaskan mengapa Korea Selatan memilih untuk memprioritaskan aspek modernisasi militer melalui pengembangan industri pertahanan domestiknya. Konsep military techno-nationalism impulse digunakan dalam penelitian ini dengan pendekatan kualitiatif, didukung dengan metode studi literatur untuk mengumpulkan data dari dokumen dan situs resmi pemerintah, jurnal, dan laporan ilmiah. Hasil penelitian menunjukkan bahwa pilihan Korea Selatan untuk mengedepankan aspek pengembangan industri pertahanan domestiknya tidak hanya dipengaruhi oleh keinginan untuk mengurangi ketergantungannya terhadap Amerika Serikat, tapi juga dilandasi oleh ambisi untuk memaksimalkan kekuatan strategis guna menghadapi ancaman Korea Utara maupun negara-negara Asia Timur lainnya yang memiliki kecenderungan antagonisme, memperoleh manfaat ekonomi yang lebih luas (wealth) melalui efek spin-off industrialisasi, serta memperoleh prestise internasional sebagai salah satu eksportir senjata terbesar, dan agar mampu berdiri sejajar dengan pemain di kawasan lainnya.
\end{abstract}

\author{
Keywords \\ Defense Reform, Military Industry, \\ Security, South Korea, Techno- \\ Nationalism
}

\section{Article History}

Received February 3, 2021

Revised March 16, 2021

Accepted March 22, 2021

Published April 3, 2021

\section{Corresponding Author}

Resi Qurrata Aini. Jl. Paus IV no.4, Ulak Karang Selatan, Padang, Sumatera Barat. 25134 


\section{Pendahuluan}

Other than the doctrinal changes and organizational reforms, the revolution in the aspect of military technology is one of the key elements of the revolution in military affairs (RMA). These kinds of fundamental changes are essential for states who want to reach better national defense and to catch up with the latest development of warfare. The United States and the Uni Soviet are the pioneers of revolution in military affairs. For the United States, It is driven by structural changes in the international system, the high investment in $\mathrm{R} \& \mathrm{D}$ and military expenditures by the government, as well as the dramatic advancements in information and communication technologies and the integration of these military, doctrinal and technological factors into new military structures and tactics (Neuneck \& Alwardt, 2008).

States hit the RMA agenda by making military technology acquisitions, doctrinal and organizational adaptations. For example, Singapore, who has acquired C4ISR-based military technology, such as the Airborne Early Warning and Control aircraft (AEW \& C) combined with the adaptation of the Integrated Knowledge-based Command and Control (IKC2) doctrine and the formation of the Future System Directorate and the Special Operations Command Center (SOCC) (Triantama \& Pangestu, 2020). However, if we examine them in detail, there are differences in the implementation of RMA in each states. Some states focus only on certain elements of the RMA and less prioritize other aspects. The implementation of RMA by middle powers such as Japan and South Korea are the perfect examples.

Status of middle power attached to Japan and South Korea is based on the capacity and capability of the state in economic, military and political aspects in the international system. States with middle power status are considered to have capabilities below great powers so that it is difficult for them to change the constellation of the international system alone (Jordaan, 2017). The middle powers, although are able to influence the behaviour or the policy of great powers, they do stay in a system orchestrated by the great powers (Robertson, 2017; Spero, 2009). Japan, with all constraints it has to bear, has focused the implementation of RMA in the doctrine and organizational aspects (Tan, 2011). Meanwhile, South Korea has focused on the implementation of RMA on the elements of military technology. This has been carried out by the South Korean government by actively building and facilitating the development of its national defense industry through various programs and policies, including Defense Reform 2020 and Defense Reform 2.0

South Korea launched the 2020 Defense Reform program which was initiated under the President Roh Moo-hyun's administration (2003-2008) in order to increase the reliability of national defense. This program set a change in military posture by reducing the number of personnel while increasing the armament of the forces and military technology (Korkmaz \& Rydqvist, 2012). The dynamics around the region, as well as changes in the types of threats and patterns of warfare that increasingly rely on technological advances, has required South Korea to developits military technology (Chang-kwoun, 2018). Those demands was responded by President Moon Jae-in in 2018 by affirming Military Reform 2.0 which called for a more streamlined and efficient Korean military, with a focus on defense sector exports (Engman \& Hannan, 2019). Defense Reform was aimed to build future-oriented self-defense capabilities, which reflect changes in the domestic and foreign security environment and the development of new defense technology (South Korean Ministry of Defense). The 2018 Defense White Paper also stated that Defense Reform 2.0 was aimed at creating a strong military, capable of taking initiatives in responding to security threats from various aspects, a military that is supported by advanced technology, and appropriate management for developed countries. Both the 2020 Military reform launched by President Roh Moo Hyun and the Military Reform 2.0 under President Moon Jae-in, explicitly mentioned the government's priorities for the development of military technology and exports of the defense industry.

Looking backwards, long before these initiatives, South Korea over-relied on the United States to support its national defense. It was the announcement of the Ghuam Doctrine by US 
President Richard Nixon in 1969 that stimulated South Korea to reduce its dependence on the United States military back up. In this doctrine, President Nixon stated that the United States would no more getting involved in the conflict in Asia, and appealed to allies in Asia not to depend on the United States and to maintain its own security (US Department of State, n.d.) This will put South Korea security at risk. In fact, South Korea also worried about its ultimate threat, namely North Korea, which could launch attacks on South Korea at anytime with no more security guarantee from United States. Not to mention the conflictual and antagonism tendency of other great powers in the region. At a certain degree, this antagonism even could lead to the security dilemma for actors in the region, including South Korea.

The military revolution of South Korea is indeed unique because it is affected by many factors, including the magnitude of the perception of threats. However, John Feffer (2009) presented a different point of view in seeing the trend of increasing military budgets in the East Asian region. He argued that in addition to fear of the competence of opposing countries, the increase in military budgets of East Asian countries was also triggered by the concerns that they would be left behind if they do not catch up with the new standards of modern wea ponry and technological advances in new types of war (Feffer, 2009). This has been pointed out as one of the triggers for East Asian countries, including South Korea, to increase their military budgets and focus on developing military technology as well. However, some of the literature has not specifically discussed matters affecting the policy choices made by the South Korean government in prioritizing the military technology revolution through the development of its domestic defense industry.

The South Korean version of the RMA initiation process has been driven by President Roh Tae-woo's administration since 1988-1992. With his military background, Roh Tae-woo paid more attention to military development by launching the "Koreanization Korean Military " program. He established a Long-Term Defense Posture Plan known as the August 18 Plan which included: (1) developing a more independent military strategy for Korea's national survival, prosperity and unification, (2) building military forces in accordance with the objectives of an independent defense strategy; (3) the development of a force structure that not only improves combat readiness, but also ensures a balanced development of armed services. They were getting clearer during the 1998-2003 Kim Dae-jung administration, which formed the Defense Reform Enhancement Committee and launched the 5-Year Defense Reform Plan. Kim Dae-jung pushed for organizational reform by creating an integrated national command system, particularly informatization of the defense sector, arming the military personnel with the latest, future-oriented weapons, and accelerate the acquisition of defense assets related to network-centric warfare, etc. (Moon \& Lee, 2008; South Korea Ministry of Defense, 2002).

The next president of South Korea, Roh-Moo Hyun (2003-2008) set an agenda for Defense Reform 2020 that focused more on high-tech troops but in smaller numbers, and balanced services in naval, army and air forces, under civilian control. Defense Reform 2020 is scheduled to reduce the number of soldiers from 650 thousand to 500 thousand by 2020, a reduction period of military conscription from 24 months to 18 months (Brookings Institutions, 2020). Furthermore, South Korea aimed to abolish the military service (conscription) and replace it with voluntary recruitment. This policy is essential if South Korea is about to maintain the credibility of its military force posture in the medium and long term (Korkmaz \& Rydqvist, 2012)

The policy of modernizing military technology seems to be a pioneer program prioritized by South Korea. It was reflected in various programs and institutions which were initiated since the Park-CungHee administration (1961-1979), including the Defense Industrial Promotion Fund program which was specifically intended for funding the South Korean defense industry. Even the current President, Moon Jae-in, also emphasized his priority in promoting the development of the defense industry as part of the Defense Reform 2.0 agenda. The serious concern of the South Korean government in modernizing military technology could also be seen from the component 
of South Korea's medium-term defense budget 2018-2023, in which the budget for the acquisition and development of weapons (force enhancement budget) has increased between $13.5-22.5 \%$ annually, much bigger than the percentage of increasing in the budget for troop operations (force operating budget) which only increased by 5.3 - 6.3\% (South Korea Ministry of Defense, 2018)

The South Korea national defense industry has experienced the benefits of of the government's persistence in building national defense industry. Now, South Korea has emerged as one of the respected military equipment manufacturers. In fact, in 1950 South Korea had only 27 M8 armored vehicles, a very small force compared to the fleet of 242 Soviet T-34 tanks used by the North Korean army at that time. Compared to current conditions, South Korea already has 2400 tanks, including the K-1 and K-2 which were produced in-house, 2,300 self-propelled artillery such as the K-9 or K-55, 3,200 armored vehicles of various types, making it one of the most armed military in the world (CHANG-WOO et al., 2019). Furthermore, not only it is able to meet its domestic needs, the South Korean defense industry has even shown its existence as a producer of weapons and military equipment such as submarines and aircraft to various parts of the world. South Korean military product exports increased sharply from 147 million US dollars in 1998, to 255 million US dollars in 2006 (Moon \& Lee, 2008)

\section{Techno-nationalism Impulse}

Techno-nationalism is a concept that explains various factors that can encourage the state to have the ability to control technology independently. David Edgerton (2007) argues that the success of a state is determined by its ability to control technology and innovation (Edgerton, 2007). Bitzinger (2015) focused on techno-nationalism in the field of military technology which is known as military techno-nationalism. Bitzinger stated that technonationalist impulse in the field of military technology is a set of goals to be achieved by the state, which underlie the mastery of weapons technology independently (autarchy). According to him, apart from nationalism, the control of weaponry technology independently is intended to maximize strategic power, gain international political status/prestige, and expand economic benefits (Bitzinger, 2015).

In an anarchic international system, the strategic power owned by a state to face threats and carry out deterrence against enemies are indeed essential in nature. These abilities would completely possessed if they are supported by the ownership of qualified military equipment. States will be more flexible to make strategic decisions in the defense sector, if the conquer the ability to fulfill military supplies independently. The ability of a state to produce military weapons/equipment also affects its image/status at the international level. A state that has a strong armed force, can be considered not credible enough if it has a dependency on other countries for their supply of weapons (Bitzinger, 2015). Other than that, the development of the military industry is also carried out to increase overall economic growth. This is possibly because it has a positive impact on other industrial sectors as well. The process of industrialization could encourage the expansion and modernization of other sectors that contribute to the national economic growth, such as steel, machine tools and shipbuilding (Willett, 1997).

The concept techno-nationalism was chosen as instrument of analysis for this research since it is able to explain the reasons for a state to develop its domestic defense industry comprehensively. As explained by Bitzinger (2015), this concept does not only look at one aspect, but touches various aspects of the interests of the state, namely power, political status / prestige and economy. Therefore, this concept is deemed appropriate to analyze South Korea's policy of carrying out military reform by prioritizing the modernization of military technology through the development of its domestic defense industry.

There are some indicators that could be assessed in analyzing the desire of a state to pursue for power, political prestige and economic benefit. The de sire to pursue for power could come from collective memory in the past that led to distrust to others. In the end, state should 
be able to overcome the threats by itself. The distrust also bring state to prevent dependency to others, including in supporting their military supply (Bitzinger, 2003; Krause, 1991; S. G. Neuman, 2010). Meanwhile, political prestige relates to the a mbition of a state to be great power in the region. Finally, the extended economic benefit can be assessed from the industrialization, arm export, and technological progress in that state.

However, the massive growth in the South Korean defense industry sector has not been followed by significant development in the aspects of the organizational and doctrinal reform that are also part of the RMA. Lots of International Relations academics and researchers, whose area of expertise are in security studies in the East Asia region, have also highlighted this point. These experts stated that South Korea did not completely adopt the RMA concept which usually refers to the United States or Russia, but had initiated its own version of the RMA. Although the South Korean military could enhance the hardware aspect of its capabilities through the modernization, its overall strategy, force structure and doctrine remained untouched because of its dependence on the US forces (Moon \& Lee, 2008). This tendency can also be seen from the absence of certain conceptual strategic innovations oriented to the South Korean RMA which lead to a new war theory, the implementation of the South Korean RMA also did not reflect a disruptive paradigm shift regarding warfare (Raska, 2011). Therefore, this paper raises the research question of why does South Korea tend to prioritize the modernization of military technology through the development of the domestic defense industry in its military reform agenda?

\section{Methods}

This research was conducted by using qualitative approach. Qualitative research is based on strategies or techniques for collecting and analyzing data that are non-numeric or based on the use of words (Lamont, 2015). The data collected in this study are the primary and secondary data. Primary data is obtained from official state documents such as the Defense White Paper, official information released by the government through press releases or official websites of the government / related ministries, etc. Documents refer to text or anything that is written, visually visible or spoken through the medium of communication (W. L. Neuman, 2004). Secondary data is obtained from literature review, printed and online mass media, as well as previous researches that has been published in reputable journals and other scientific reports.

Furthermore, those data will be categorized based on research variables and indicators. The dependent variable in this study is South Korea's policy that prioritize the modernization of military technology through the development of its national defense industry. The independent variables in this study consist of three aspects mentioned in Figure 1 referes to the concept of techno-nationalism, namely South Korea's desire to maximize strategic power, to gain international prestige/status and to obtain broader economic benefits. Data analysis will be carried out by using triangulation techniques to clarify and cross-check the data obtained on the research variables and indicators. Furthermore, the author will describe the causal mechanism between variables so that the research questions can be addressed scientifically.

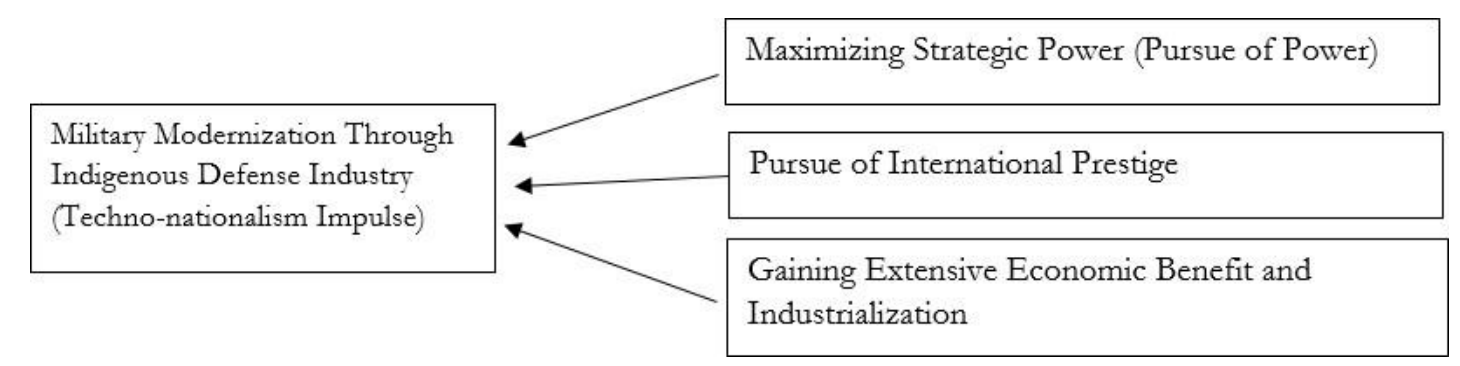

Figure 1. Analytical Model based on Bitzinger (2015) 


\section{Result and Discussion}

Before unpacking the research findings, we will first discuss the policies and developments of the South Korean defense industry. This is essential to obtain an overview of how the South Korean government prioritizes aspects of military modernization and technological innovation, through the development of its domestic defense industry. After the end of the Japanese occupation in Korea from 1945 to 1968, South Korea completely depended on the United States for its military equipment needs. This security and military assistance from the United States, combined with the weakness of domestic industry, finance and skilled manpower, prevented South Korea from developing its defense industry independently (Moon, 1991) At that time, Korea was not even capable of producing light weapons, let alone airplanes. Conditions that were contrary to the current achievements of Korea, which is known as a developed and leading industrial country, as well as a world leaderin the shipbuilding, motorbike manufacturing and information technology industries (Korkmaz \& Rydqvist, 2012)

Despite the fact that the defense industry is still relatively small in scale compared to other industrial sectors in South Korea (Hackett and Mark Fitzpatrick, ed., 2018, p. 41), South Korea's defense industry has experienced development following various government programs that facilitate the growth of the domestic defense industry, and there is a strong desire to pursue the export market (Korkmaz \& Rydqvist, 2012). These developments can be seen, among others, from the increase in sales of South Korean defense industrial products every year. Military exports increased from 147 million US Dollars in 1998, to 155 million US Dollars in 2006 (Moon \& Lee, 2008). This significant development aslo reflected in the report of Korean Defense Industry Association which stated that the export value of South Korea's defense industry experienced a significant upward trend in the period 2008 - 2017 as shown in Figure 2 below. In 2008, defense industry exports started from US \$ 1.03 million before going upward to be 1.18 million US Dollars, and then reached 3.12 million US Dollars in 2017.

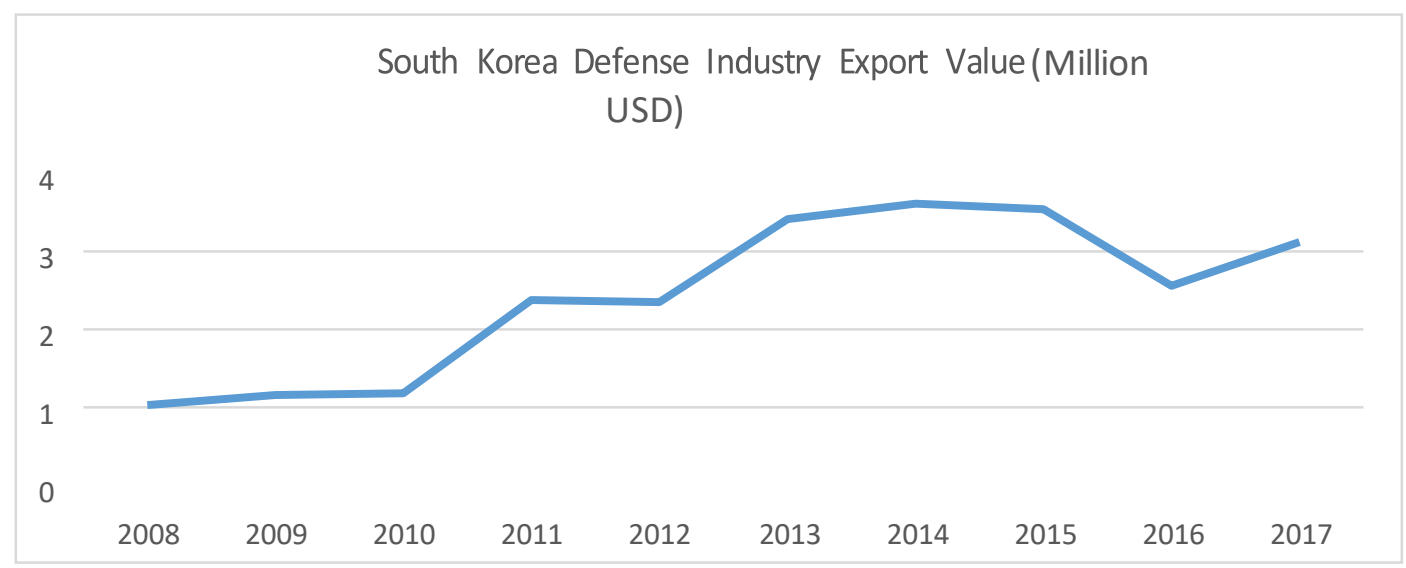

Figure 2. South Korea Defense Industry Export Value based on Korea Defense Industry Association data

\section{Maximizing Strategic Power (Pursue of Power)}

1. Antagonism in the Region and Arm Race

East Asia and around, the strategic environment surrounding South Korea, is a unique region with competition among the actors and conflict-prone characteristics. Take the relations with Japan as an example. Although both South Korea and Japan share same ally, the United States, it is still difficult for them to become close ally. South Korea was under Japanese rule from 1910 to 1945 as stipulated in the Japan-Korea Treaty 1910. During that time, South suffered the imperialism brutality from Japan. Until now, this dark history has influenced the relationship between the two countries. In 2018, South Korea and Japan relations deteriorated, some media 
even mentioned it as the worst period of South Korea - Japan relations since the normalization agreement in 1965. Both of them excluded each other from the white list of export destination countries. Japan restricted the export of high-tech spare parts which were vital to South Korea. It was brought South Korea's technology-based defense industry into big trouble when the Japanese Ministry of Commerce announced a temporary ban / suspension of export permits for materials vital to the South Korean semiconductor industry such as liquid hydrogen fluoride - a pure chemical used to produce chips (Bloomberg, 2019). Semiconductors are a source of income for Korean giant tech company, Samsung, and contributes up to $20 \%$ of South Korea's total exports (Kim, 2019; Bloomberg, 2019). Therefore, it is indeed essential for South Korea to gain its power by increasing the capability of the defense industry independently so that it can prevent this kind of pressure comes from dependencies in the future.

South Korea also has to consider the indications of arms race among great powers in the region. This can be seen from the massive import of weapons and the large budget and defense spending of regional players in the Asia Pacific. During the 2011 -2015 period, SIPRI recorded the Asia Pacific region as the largest importer of weapons, about $46 \%$ of the total arms imports of all countries in the world (Oi-Hyun, 2017). Not to mention that five Asia Pacific states, namely China, India, Japan, South Korea, and Australia, are among the top 15 countries with the largest military budgets in the world, with a total of $28 \%$ of all military budgets of all countries in the world (Engman \& Hannan, 2019).

Furthermore, the competition among Asia Pacific states was also cherished by the rise of China's assertiveness. However, other Great powers in the region are aiming to maintain the status quo. Those external factors, namely the rise of China and increasing aggression in the regional security infrastructure, also encouraged President Moon to declare defense reform as the top priority of his administration focusing on exports of the defense industry sector (Engman \& Hannan, 2019). South Korea cay not rely solely on the acquisition of weapons from other countries. In one hand, South Korea has to obey the alliance rules of the United States which limit the flexibility of South Korea to purchase and sale of weapons from third parties. In the other hand, depending too much on meeting the needs of weapons from other countries, is a risky choice either. Countries become vulnerable to embargoes or technology withdrawals, which pose the risk of reducing the ability to fulfill weapons which are crucial for their defense needs (Bitzinger, 2015) Thus, this further encouraged South Korea to maximize domestic production of weapons by prioritizing the development of the domestic defense industry.

\section{Tension in Korean Peninsula}

Other pressures faced by South Korea are related to the never-ending tensions on the Korean Peninsula. South Korea has high perception of threat that comes from the North Korean, due to nuclear testing and proliferation activities carried out by North Korea. When a state witnesses another state arming itself, it will be considered aimed at destroying its security; a hostile image is attached to that state (Arif, 2016). South Korea has actually tried to minimize potential tensions with a series of defense diplomacy by arranging trust-building process and several military dialogues. From the 1990 s to 2020 , at least 169 military dialogues between the two countries were recorded (South Korea Ministry of Defense, 2020). However, the South Korean Ministry of National Defense explicitly stated that there had been no significant progress in building military trust with North Korea due to the continuing threats and provocations acts by North Korea. Those provocations including nuclear proliferation ballistic missiles testing, development of conventional forces, armed provocations in border areas, cyber attacks, and various other acts of provocation (South Korea Ministry of Defense, 2018). Although the condition was quite calm without ballistic missile tests in 2018 when the Panmunjon Declaration was signed, this condition did not persist due to the stagnation of coercive diplomacy efforts by United States to denuclearize North Korea. 
Table 1. South Korea - North Korea Defense Posture Comparison

\begin{tabular}{|c|r|r|}
\hline \multicolumn{3}{|c|}{ South Korea-North Korea Defense Posture Comparison } \\
\hline Total & North Korea & South Korea \\
\hline Army & 1.280 .000 & 590.000 \\
\hline Navy & 1.100 .000 & 464.000 \\
\hline Airforce & 60.000 & 70.000 \\
\hline Paramilitary & 110.000 & 65.000 \\
\hline Reserve & 5.700 .000 & 9.500 \\
\hline Tank & 4.160 & 3.100 .000 \\
\hline Aircraft & 545 & 2.221 \\
\hline Submarine & 73 & 567 \\
\hline Artilery & 21.100 & 22 \\
\hline Source: Author & 11.067 \\
\hline
\end{tabular}

Source: Authors Calculation based on IISS (2020)

Table 1 above shows that South Korea defense posture is still left behind The North Korea in almost all the material aspects. For example, North Korea's active and reserved personnel outperformed South Korea by more than 100\% (IISS, 2020). South Korea only outperformed The North in the aircraft quantity. These brought South Korea in such an insecure position against North Korea. This fact inevitably increases the urgency to improve South Korea's armaments both in quantity and quality. South Korea Perception toward North Korea as the ultimate threat, has required South Korea to be able to defense itself. In order to defend its territory integrity, the country needs a reliable source of supplies of weapons, namely those from domestic production (Bitzinger, 2015: 455). South Korea has the advantage in terms of technology innovation and better economic growth compared to North Korea. South Korean government makes optimal use of their strength by encouraging national defense industry to create various weapons technology innovations that simultaneously strengthen its military. In the end, this effort would contribute in maximizing its strategic power against the threats.

\section{International Prestige: Gaining Influence in The Third World and Standing equal to Other Great Powers in The Region}

The atmosphere of competition among the Asia Pacific states inevitably influences South Korea to strive for a status to be proud of. This competitive atmosphere cannot be separated from historical factors. Historically, South Korea was under Japanese rule for more than forty years. South Korea suffered from Japan's colonial brutalities, such as "comfort women" that often affects the dynamics of South Korea-Japan diplomatic relations (Shin, 2021). In addition, South Korea relations with China and Russia offered nothing except similar conditions. China's antagonism to South Korea can be seen in several cases. First, when the Korean War broke out, China only recognized North Korea's sovereignty but not South Korea until 1992 (Liu, 1993). Secondly, there was a territorial dispute between the two countries for Socotra Rock. The dynamics of the relationship between the two countries has resulted the South Korean perception toward China as one of their biggest security threat (Chung, 2012). So did Russia, who did not aknowledge the existence of South Korea for deaceds. Diplomatic relations between the two were just established in 1990 (Hyung-dae, 2019). Theese historical facts shows that South Korea struggled from the very beginning to get recognition from great powers in the region. Therefore, South Korea has an urge in showing its existence as a nation that used to suffer to become a great and independent 
nations. Independence on military technology, even being able to export military weapons and equipment, are such a huge pride for South Korea.

Based on data released by the Stockholm International Peace Research Institute (SIPRI) Arm Transfer Database, from 2010 to 2018, South Korean arms exports have increased quite significantly. However, in this SIPRI release, it is necessary to take a note that the indicators used do not refer to the export value, but rather an assessment of the types and capabilities of the military presented by each exported weapon, namely the Trend Indicator Value (TIV) (Holtom et al., 2012). TIV was developed and used by SIPRI in order to see the trends in arms sales each year. In the context of South Korean arms exports, the value of South Korean arms sales was 197 million TIV in 2010, and reached 1.06 billion TIV in 2018 which was also the largest export value in that period (Wezeman et al., 2019).

Compared to China and Russia, which are also known as arms exporters, South Korea's total arms sales are indeed lower. Based on SIPRI data, the value of China's arms sales was 1.14 billion TIV the smallest and the highest reached 2.37 billion TIV for 2010 - 2018 period. Meanwhile, the total of Chinese arms sales in that period amounted to 14.25 billion TIV (Wezeman et al., 2019). Nothing different with comparison with Russia, the value of South Korean arms sales is still lower. Russia as the second largest arms exporter in the world is able to record sales of up to 8.7 billion TIV and the lowest worth 5.5 billion TIV (Wezeman et al., 2019).

Nonetheless, the increasing trend of South Korean arms sales as previously mentioned remains a great achievement for South Korea. Not only has recorded an increase of up to $548 \%$, South Korea also succeeded in positioning itself as one of the world's largest arms exporter. During 2014 - 2018, South Korea controlled 1.8\% of the world arms trade while being ranked 11 th in the world arms exporter and 2nd in Asia (Wezeman et al., 2019). This strengthens South Korea's position as a regional player with the capability of standing on position with other great powers in the region.

Moreover, not only able to compete with great powers in the region, South Korea has also succeeded in achieving the status as the third largest arms exporter in The Third World since 1990 (Moon, 1991) South Korea even has the ambition to achieve status as a developed country in the aviation industry and set the target to achieve 7 th position in the world by 2020 , as stated by the Head of the South Korean Aviation Industry Association in the 2015 Aviation Industry report,

In the field of aircraft, The Korean helicopter Surion development was officially completed, making South Korea into the world's 11th country to indigenously develop helicopters, and the Korean Supersonic aircraft T-50i was exported to Indonesia in a ferry flight, making Korea the world's sixth country to export a supersonic aircraft. Also Korea made a great achievement in export by signing a 1.1 billion dollar deal to deliver FA-50 aircraft to Iraq, the largest amount in the history of national defense export... Based on the "Basic Plan for The Development of Aircraft Industry", the blueprint which aims to place Korea among the top 7 global position by 2020 (Korea Aerospace Industries Association, 2015)

The empirical facts explained in this research shows that South Korea has now become one of the world's arms exporters, which is in line with Bitzinger's argument in his 2015 article. Bitzinger stated that even though the development of the defense industry is an expensive investment for Asian countries, they remain persistent in developing the national defense industry. This is mainly because the success of the national defense industry in producing weapons will increase the prestige and status of the country in the international system. The prestige will even be greaterif they are able to export their own manufactured defense product.

\section{Gaining Extensive Economic Benefit and Industrialization}

Funding and resources are ultimately needed by states to build up their national defense industry. Therefore, not all states are able to manage their national defense industry 
independently, many states prefer buying military supply and equipment they need from others, and some other maintain partnership with developed countries for providing financing assistance for the acquisition of military equipment. Meanwhile, South Korea carefully regulates the financing of its Defense Reform Program, but still gives priority to upgrading military technology in line with the main Defense Reform 2020 agenda. From the total Defense Reform budget of 650 billion dollars, the largest allocation is given to the Troop Improvement Program after troop operational costs (salaries, food and clothing), which consists of both independent and imported weapons procurement, acquisition, and independent weapons Research and Development (R\&D), amounting up to 227.1 billion dollars (Ju-Hyun, 2009).

In the other hand, the expansion of the defense industry is expected to contribute positively to economic growth. Previous researchers have conducted a lot of research on the correlation between military budgets and spending with states' economic growth. The result shows that positive impact is not always be direct, but can be indirect as well, such as reviving other industrial sectors (encourage industrialization), opening up new jobs, increasing technological innovation and having a positive effect on improving human resources (Chairil et al., 2013; Deger \& Smith, 1983; Paul Dunne, 2013).

However, defense budget does not necessarily have a positive correlation with economic growth. There is no direct impact between defense spending on South Korea's economic growth (Heo, 1996). However, it cannot be denied that the development of the military industry also encourages the growth of other supportive industrial sectors that provide raw materials and supporting spare parts, such as the iron, steel, aluminum industry as well as the experts. In other words, the military industry has a spin-off effect on other sectors. For example, the South Korean warship building industry, in building ship hull construction, also requires a supply of materials from the steel industry as well as the automobile industry which provides supporting components such as armor plating, chassis, and engines, not to mention the increasing need for trained manpower needed to produce high-tech military vehicles/equipment (Bitzinger, 2015).

Therefore, it can be inferred that the defense industry has such a domino effect in encouraging industrialization as a whole. The economic benefits obtained are not limited to the profit from producing defense product from defense industry itself. Nevertheless, broader effect enjoyed by national economy as a whole through the industrialization process of various sectors which is driven by the development of the defense industry. Several sectors facilitated by the South Korean government in building up the defense industry, including the aircraft manufacturing and the semiconductor industry. South Korea succeeded in agreeing to sell FA50 aircraft to Iraq with a value of 1.1 billion dollars, which is the largest sales figure in the history of South Korean defense exports (Korea Aerospace Industries Association, 2015). Likewise, the semiconductor industry has a significant effect of $20 \%$ of South Korea's total exports (Kim, 2019).

\section{Conclusion}

The international system, which is anarchic in nature, encourages states to strive for fulfilling their military equipment needs. One of the way is by building up theirnational defense industry independently. However, the agenda to develop their own defense industry is not always in favour for all states. For the case of South Korea, it experienced high dependencies toward the United States to supply its defence needs for too long. Apart from relying on backup from the United States military, South Korea is also vulnerable to embargoes and regulations on the sale and acquisition of weapons/ military equipment from third parties as required by the United States. South Korea has limited freedom to determine its military policy. These constraints inevitably made the South Korean military used to be left behind other states 
in the region. Thus, South Korea had to eradicate this dependency. South Korea then initiated its own version of the RMA by emphasizing the technology-based military modernization. In order to achieve military independence, the South Korean Government strongly encourages the development of their national defense industry by providing various funding system, regulatory facilities and incentives for contractors and defence companies to start up their business.

By using the concept of military techno-nationalism, there are at least 3 factors that encouraged South Korea to prioritize the independence of the defense industry as the first step to support its RMA. Firstly, the development of the defense industry is driven by the desire to maximize strategic power. South Korea is located in a region that is full of competition and conflict-prone that lead to an arms race. China and Russia are two great powers in the region with huge military budgets, who tend to be in antagonism with South Korea and make friend with its ultimate threat, North Korea. Not to mention its volatile relations with Japan even though they were both an alliance of the United States. In addition, the security of the Korean peninsula which always been South Korea's main concern. After all, South Korea needs a capable military force supported by an adequate supply of weapons. However, being dependent to others is not always be in favor for South Korea. Thus, the reliable sources of supply of weapons is the domestic defense industry.

Secondly, the desire to gain international prestige and to be able to stand equal to other great powers in the region also encouraged South Korea to develop its national defence industry. South Korea now is among the first tierin the shipbuildingindustry in Asia, especially military submarines, and has the ambition the 7 th greatest world's aircraft manufacturers. South Korea also achieved the status of the third largest arms exporter in a Third World Country. Quoting Bitzinger's (2015) argument, that even a country that has a sophisticated military force will have less credibility if it has a dependency on supplies of weapons from other countries. Therefore, the ability of South Korea to produce military aircraft and submarines independently and to be known as an arms exporter, is such a prestige among other East Asian countries and at the global level as well.

Last, but not least, there is a desire to obtain broader economic benefits from the industrialization process of national defense. Although it is not necessarily be direct, the development of the defense industry sector also stimulates otherindustrial sectors that support the production of military equipment. In addition, the defense industry can also encourage the creation of a variety of employment opportunities and increase the quality of human resources, especially the experts and skilled workers in the field of military technology.

In the end, it can be concluded that in spite of the desire to decrease military dependencies toward the United States, the policy to build South Korea's national defense industry can not be separated from all variables of the techno-nationalism impulse concept. The ambition to maximize strategic power amidst North Korea's threat and competition in the East Asian Region, gain the international status/reputation as a respected arms exporter country, and the desire to obtain broader economic benefits, prompted the South Korean government to take priority steps to develop the domestic defense industry in the framework of modernizing military technology. This action taken as part of the 2020 Military Reform agenda that seeks to achieve military independence. This policy then contributed to the initiation step of the South Korean version of RMA characterized by military technological revolution. 


\section{References}

Arif, M. (2016). How Threat Assessment Could Become Self-Fulfilling Prophecy: Case of U.S.- China Relations. Global: Jurnal Politik Internasional, 18(2), 120. https://doi.org/10.7454/global.v18i2.140

Bitzinger, R. A. (2003). Towards a Brave New Arms Industry. Routledge.

Bitzinger, R. A. (2015). Defense Industries in Asia and the Technonationalist Impulse. Contemporary Security Policy, 36(3), 453-472. https://doi.org/10.1080/13523260.2015.1111649

Bloomberg. (2019). Japan delaying export of key chipmaking material beyond 90 -day limit, South Korea says. Japantimes. https://www.japantimes.co.jp/news/2019/10/01/business/japan- delaying-exportchipmaking-material-south-korea/\#.XpfvjsgzbIU

Brookings Institutions. (2020). Korean Defense Reform: History and challenges. Brookings. https://www.brookings.edu/research/korean-defense-reform-history-and-challenges/

Chairil, T., Sinaga, D., \& Febrianti, A. (2013). Relationship between Military Expenditure and Economic Growth in ASEAN: Evidence from Indonesia. Journal of ASEAN Studies, 1(2), 90. https://doi.org/10.21512/jas.v1i2.63

Chang-kwoun, P. (2018). The Moon Jae-in Administration's Defense Reform 2 . 0 : Direction and Considerations. 184, 1-6.

Chang-Woo, K., Hong-Jun, K., \& Kyu-Seok, S. (2019). Korea climbs ranks of global arms exporters. Korea Joong Ang Daily.

https://koreajoongangdaily.joins.com/2019/08/08/politics/Korea-climbs-ranks-ofglobal-armsexporters $/ 3066510 . \mathrm{html} \#: \sim$ :text $=$ Compared to $2006 \% 2 \mathrm{C}$ when the, in arms and military

Deger, S., \& Smith, R. (1983). Military Expenditure and Growth in Less Developed Countries. The Journal of Conflict Resolution, 27(2), 335-353. http://www.jstor.org/stable/173707

Edgerton, D. E. H. (2007). The Contradictions of Techno-Nationalism and TechnoGlobalism: A Historical Perspective. New Global Studies, 1(1). https://doi.org/10.2202/1940-0004.1013

Engman, \& Hannan, J. (2019). Ambition and Ambiguity: South Korea's Defense Industry Reform. ISDP. https://isdp.eu/ambition-and-ambiguity-south-koreas-defense-industryreform/

Feffer, J. (2009). Introduction to the Special Issue : AN ARMS RACE IN NORTHEAST ASIA ? Asian Perspective, 33(4), 5-15.

Heo, U. (1996). The Political Economy of Defense Spending in South Korea. Journal of Peace Research, 33(4), 483-490.

Holtom, P., Bromley, M., \& Simmel, V. (2012). Measuring international arms transfers (Issue December). https://www.sipri.org/sites/default/files/files/FS/SIPRIFS1212.pdf

Hyung-dae, K. (2019). Next year, Korea and Russia celebrate meaningful 30 th anniversary of diplomatic relations. The Korea Post.

http://www.koreapost.com/news/articleView.html?idxno=9241

IISS. (2020). Military Balance. In International Institute for Strategic Studies.

Jordaan, E. (2017). The emerging middle power concept: Time to say goodbye? South African Journal of International Affairs, 24(3), 395-412. https://doi.org/10.1080/10220461.2017.1394218

Ju-Hyun, P. (2009). The ROK Defense Budget and Defense Reform. 15, 1-4.

Kim, S. (2019). Japan Delays Export of Key Chipmaking Material to South Korea. Bloomberg. https://www.bloomberg.com/news/articles/2019-09-19/japan-delays-export-of-keychipmaking-material-to-south-korea 
Korea Aerospace Industries Association. (2015). Korea Aerospace Industry 2015. 64.

https://www.flandersinvestmentandtrade.com/export/sites/trade/files/market_studi e s/28150507103312/28150507103312_3.pdf

Korkmaz, K., \& Rydqvist, J. (2012). The Republic of Korea : A Defence and Security Primer. In FOI.

Krause, K. (1991). Military Statecraft: Power and Influence in Soviet and American Arms Transfer Relationships. International Studies Quarterly, 35(3), 313. https://doi.org/10.2307/2600702

Lamont, C. (2015). Researh Methods in Politics and International Relations. Sage Publications.

Liu, H. (1993). The Sino-South Korean Normalization: A Triangular Explanation. Asian Survey, 33(11), 1083-1094. https://doi.org/10.2307/2645001

Moon, C. (1991). THE POLITICALECONOMY OF DEFENSE INDUSTRIALIZATION IN SOUTH KOREA : CONSTRAINTS, OPPORTUNITIES, AND PROSPECTS. The Journal of East Asian Affairs, 5(2), 438-465.

Moon, C., \& Lee, J.-Y. (2008). The revolution in military affairs and the defence industry in South Korea. Security Challenges, 4(4), 117-134.

Neuman, S. G. (2010). Power, influence, and hierarchy: Defense industries in a unipolarworld. Defence and Peace Economics, 21(1), 105-134. https://doi.org/10.1080/10242690903105398

Neuman, W. L. (2004). Basics of Social Research: Qualitative and Quantitative Approaches. Pearson.

Neuneck, G., \& Alwardt, C. (2008). The revolution in military affairs: Its driving forces, elements, and complexity. In The Revolution in Military Affairs, its Driving Forces, Elements and Complexity? (No. 13; IFAR Working Papers). https://doi.org/10.1002/cplx.20236

Oi-Hyun, K. (2017). Reportspoint to a new arms race breaking in the Asia Pacific region. Hani.Co.Kr. http://english.hani.co.kr/arti/english_edition/e_international/731678.html

Paul Dunne, J. (2013). Military Keynesianism: An assessment. Contributions to Conflict Management, Peace Economics and Development, 20(PART2), 117-129. https://doi.org/10.1108/S1572- 8323(2013)00020.2011

Raska, M. (2011). RMA diffusion paths and patterns in South Korea's military modernization. Korean Journal of Defense Analysis, 23(3), 369-385.

Robertson, J. (2017). Middle-power definitions: confusion reigns supreme. Australian Journal of International Affairs, 71(4), 355-370. https://doi.org/10.1080/10357718.2017.1293608

Shin, M. (2021). Conflict Between South Korea and Japan Surges Again With Court's 'Comfort Women' Decision. The Diplomat. https://thediplomat.com/2021/01/conflict-between-southkorea-and-japan-surges-again-with-courts-comfort-women-decision/

South Korea Ministry of Defense. (2002). Gukbang Jeongchaik (National Defense Policy) 1998 2002.

South Korea Ministry of Defense. (2018). Defense White Paper.

South Korea Ministry of Defense. (2020). Establishment of Military Trust in Inter-Korean Relations. Defense Policy.

https://www.mnd.go.kr/mbshome/mbs/mndEN/subview.jsp?id=mndEN_0302000 00000

Spero, J. B. (2009). Great power security dilemmas for pivotal middle power bridging. Contemporary Security Policy, 30(1), 147-171. https://doi.org/10.1080/13523260902760355

Tan, A. (2011). East Asia's Military Transformation: The Revolution in Military Affairs and its Problems. Security Challenges, 7(2), 71-94. 
Copyright (C) 2021, Resi Qurrata Aini, Febry Triantama

This is an open access article under the CC-BY-SA

license
ISSN 2088-8090 (Print) ISSN 2597-6648 (Online) Sospol: Jurnal Sosial Politik Vol 7 No 1 (2021), pp.63-76

Triantama, F., \& Pangestu, Y. (2020). Revolution in Military Affairs : Strategi Menghadapi Strategic Disadavantage Singapura. Nations State: Journal of International Studies, 3(2), 195206.

US Department of State. (n.d.). Foreign Relations of The United States, 1969-1976, Volume I, Foundations of Foreign Policy, 1969-1972. Office of the Historian. https://history.state.gov/historicaldocuments/frus1969-76v01/d29

Wezeman, P. D., Fleurant, A., Kuimova, A., Tian, N., Wezeman, S. T., \& The. (2019). Trends in international Arms Transfer (Issue March). https://doi.org/10.1016/b978-0-08-101276$5.00003-\mathrm{x}$

Willett, S. (1997). East asia's changing defence industry. Survival,39(3), 107-134. https://doi.org/10.1080/00396339708442929

Young-sup, H. (2006). Analyzing South Korea's Defense Reform 2020. The Korean Journal of Defense Analysis, 18(1), 111-134. 